\title{
Influence of Burrow Holes in Residual Soil Slope Infiltration
}

\section{Zaihasra Abu Talib ${ }^{1, *}$, Azman Kassim², Gambo Haruna Yusak ${ }^{3}$, Mohd Fairus Mohd Yusof ${ }^{1}$, Felix Ling Ngee Leh ${ }^{1}$,} \author{
Universiti Tun Hussein Onn Malaysia, 86400 Johor, MALAYSIA \\ ${ }^{2}$ School of Civil Engineering, Faculty of Engineering, \\ Universiti Teknologi Malaysia, 81310 Johor, MALAYSIA \\ ${ }^{3}$ Department of Civil Engineering, Faculty of Engineering, \\ Bayero University, Kano, NIGERIA \\ *Corresponding Author
}

${ }^{1}$ Department of Infrastructure and Geomatic Engineering, Faculty of Civil and Environmental Engineering,

DOI: https://doi.org/10.30880/ijie.2019.11.01.030

Received 20 July 2018; Accepted 15 December 2018; Available online 15 May 2019

\begin{abstract}
Infiltration rate is important factors in the rainfall induced slope failure. The infiltration of water into residual soil was govern by rainfall intensity and also saturated permeability of soil. The existing of burrow holes has proven increases the permeability of the soil with increase in number of burrow holes. Therefore, it is very important to study the effect of burrow holes in residual soil slope and its effect in infiltration rate. The modified constant head permeability was done to study effect of burrow holes in residual soil. Then, the infiltration test was done to study the infiltration rate of residual soil with existing of burrow holes. The result from modified permeability shows that permeability of residual soil increases from $5 \times 10^{-7} \mathrm{~m} / \mathrm{s}$ to $1.14 \times 10^{-3} \mathrm{~m} / \mathrm{s}$ for different area of burrow holes. The result from infiltration test proven that when $\mathrm{q} / \mathrm{k}_{\text {sat }}$ greater than 1 the runoff was occurs. Meanwhile, when $\mathrm{q} / \mathrm{k}_{\mathrm{sat}}$ less than 1 infiltration was occurs. The result also indicates that the smaller ratio between of resq/ $\mathrm{k}_{\text {sat }}$, the faster the infiltration of water into the soil.
\end{abstract}

Keywords: Residual soil slope, matric suction, burrow holes and infiltration rate.

\section{Introduction}

Rainfall-induced slope failure are common problems in many tropical areas covered by residual soil. Failure mechanism of slope normally happened because of two factors, which are, rainfall intensity and coefficient of saturated permeability, $\mathrm{K}_{\text {sat }}[1]$. These two factors were controlled the infiltration rate in the residual soil slope. Thus, affect the slope stability and cause the landslide to happen.

The tropical residual soil mantle derived from igneous rocks mainly consists of materials dominantly decomposed to Grades IV and V according to the six-fold weathering classification system of International Society for Rock Mechanics (ISRM) (1981) of saprolitic soils, and true or mature residual soil (Grade VI) of laterites (Bland \& Rolls, 1998; Taylor \& Eggleton, 2001; Aydin, 2006). This will cause the rock lost their original rock fabric. The weathering process involves in the formation of residual soil introduces variation in material scale and also in field scale. In material scale, the weathering process cause the igneous rock decomposed to Grade IV (lateritic layer) and V (saprolitic layer). Therefore, it is produces variations in grain size, porosity, mineralogy, lithologic texture, rock mechanical properties, structure and diagenetic processes. In field scale, the variation in residual soil because of discontinuities in soil mass such as relict joints, bedding planes, foliations, faults and shears happened in saprolitic layer. While in 
lateritic layer, study [2] prove that insect population such as burrow holes govern the properties of soil such as density and hydraulic properties of soil. Permeability of lateritic layer can be up to $0.01 \mathrm{~m} / \mathrm{s}$ and to $1 \mathrm{~m}$ depth with existing of burrow holes [3]. Meanwhile, permeability of saprolitic soil is varies with depth, the variation of permeability in this layer is within two orders of magnitude [4], [5].

Many studies such as Kassim et al., (2012), Kim and Lee, (2013), Lee, Kassim, Gofar, (2011) and Trandafir et al. (2007) concluded that matric suction play important role in slope stability especially in residual soil. The slope failure happened due to total or partial loss of matric suction during rainfall infiltration and causes the shear strength of soil decrease. In initial condition, with higher matric suction has greater initial factor of safety in slope stability. However, during rainfall, the matric suction decrease and factor of safety also decline. It is shows that matric suction contributes to the shear strength of soil. The rainfall intensity and duration affect the suction distribution in intermediate saturated permeability soil such as sandy silt, which is common type of residual soil (Gofar and Lee, 2008). Suction distribution in coarse-grained soil influenced by short and heavy rainfall. Meanwhile, the prolonged rainfall more influenced suction distribution in fine-grained soil (Gofar and Lee, 2008).

Many studies on effect of rainfall infiltration in residual soil is done widely [6-11]. The effect of suction distribution on slope stability is main focus for above studies. Most of the study use numerical modeling in their study. This is because many factors that contribute to this process and using numerical modeling all these factors can easily controlled.

The existing of the cracks in the soil especially at upper layer of the soil Novak (2000) shows that existing of joint in residual soil changes the infiltration capacity of soil. The infiltration capacity of the soil without cracks is less than half $(34 \%)$ of the infiltration capacity of the soil with cracks. The existing of relict joint also influence the suction distribution in the residual soil due to different in hydraulics conductivity and the capillary barrier effect [12].

However, the previous study only focusing on saprolitic layer with one type of relict joint and ignore profiling of lateritic joint. Most of the previous studies on suction distribution in heterogeneous soil focused more on numerical and analytical investigation. Thus, it is imperative to provide laboratory evidences for verification purpose.

\section{Methodology}

The sloping area with residual soil profile was the scope of this study. Therefore, Balai Cerap, Universiti Teknologi Malaysia, Skudai was selected as the study area. Overall, the geometry of the Balai Cerapan's slope is uniform, and the slope appears to be a cut slope. The slope angle at the study area is approximately $21^{\circ}$. The height and length of the slope is about is approximately $17 \mathrm{~m}$ and $47 \mathrm{~m}$, respectively. The location for field work is shown in Fig. 1 .

Based on the soil layering arrangement at the site determined during the trial pit excavation, samples obtained from the first layer (i.e. $0 \mathrm{~m}$ to $0.5 \mathrm{~m}$ ) were generally fine-grained in nature without presence of boulders therefore regarded as grade VI (i.e. residual soil). Immediately below $0.5 \mathrm{~m}$ depth coarser material were encountered with presence of heterogeneity such as corestones and relict joints, therefore, samples taken below $0.5 \mathrm{~m}$ were considered grade V (i.e. completely weathered rock).

The undisturbed sample was taken for purposes engineering testing. Summary of testing involved as shown in Table 1. Identification of soil properties are according to British Standard, BS 1377 Part 1-9; 1990 and American Society of Testing Method, ASTM: D2325-68: 2000. However, some testing was tested according to manufacturer procedures and guidelines.

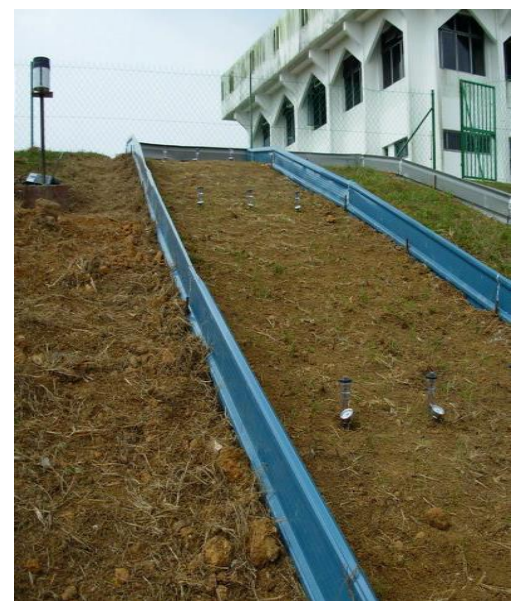

Fig. 1 - Study area 


\subsection{Modified Constant Head Permeability Test}

The effect of burrow holes in Grade VI cannot be done using standard permeability test. Therefore, the modified permeability based on constant permeability test as follows BS 1377: Part 5: 1990: 5 was introduced. The modified permeability test is to determine saturated hydraulic conductivity, $\mathrm{k}_{\mathrm{sat}}$ of soil with present of burrow holes. The infiltration cell was made of steel framed with acrylic sheet sidewalls, $750 \mathrm{~mm}$ length, $200 \mathrm{~mm}$ height, and $150 \mathrm{~mm}$ width as shown in Fig. 2. The artificial burrow holes were simulated by using steel bar to make a hole. Test was done using steel bar size $3 \mathrm{~mm}, 5 \mathrm{~mm}$ and $12 \mathrm{~mm}$ in diameter with different numbers of holes 3,5 and 10 numbers of holes.

Table 1 - Testing for index properties of soil

\begin{tabular}{cc}
\hline Test & Standard \\
\hline Sieve Analysis & BS 1337 : Part 2 \\
Hydrometer test & BS 1337 : Part 2 \\
Atterberg limit test & BS 1337 : Part 2 \\
Specific gravity & BS 1337 : Part 2 \\
\hline
\end{tabular}

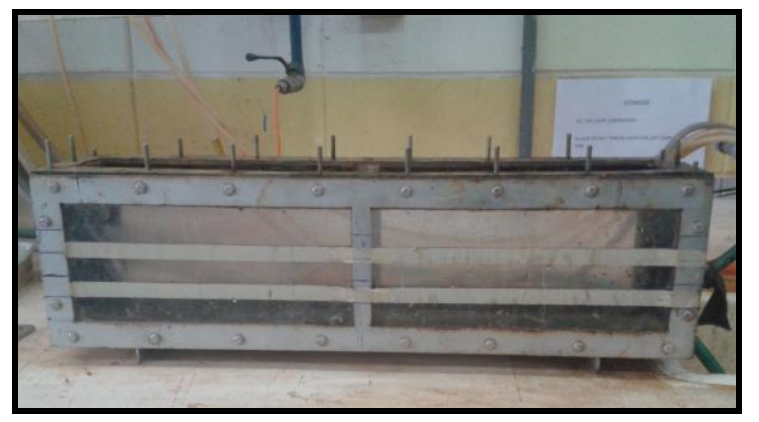

Fig. 2- Modified constant head permeability equipment

\subsection{Infiltration test}

Infiltration test is consists of infiltration model, rainfall simulator, measuring sensor and data logger system. The purpose of this work is to identify the suction distribution and also the flow mechanism of heterogeneity of residual soil slope as mention in objectives of this study.

Infiltration model box was $1000 \mathrm{~mm}$ in length, $300 \mathrm{~mm}$ in width and $800 \mathrm{~mm}$ in height as shown in Fig. 3 and the schematic diagram for this infiltration model box shown in Fig. 4. The frame of model was made of stainless steel and the sidewalls were made from acrylic sheet $5 \mathrm{~mm}$ thickness. This is because the visual observation can be done during infiltration test. Three types of boundary condition were applied, zero-flux boundary was applied at both length of side wall and a unit hydraulic gradient flow was applied at bottom of model. At toe of the slope, outlet was located at top of the model to create no-ponding upper flux boundary during testing.

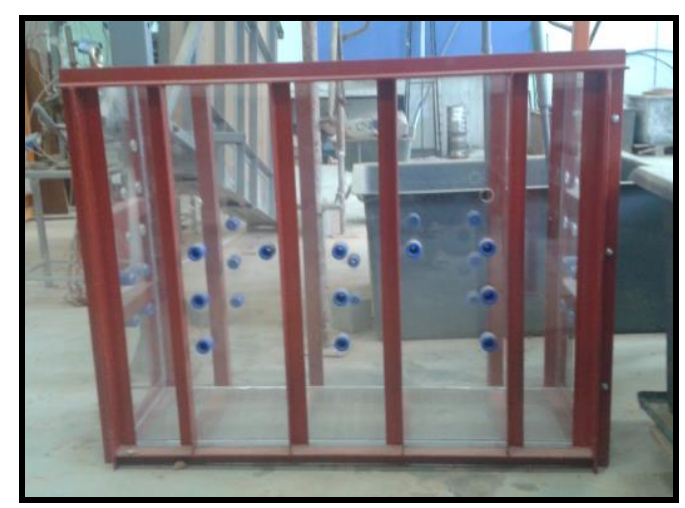

Fig. 3 - The infiltration model box

The rainfall simulator consists of rainfall simulator frame, water tank, outlet valve and motor. Rainfall simulator frame was $1200 \mathrm{~mm}$ in length and width. The rainfall was generated by using 8 outlet valve distributed at $100 \mathrm{~cm}$ 
spacing constructed from $12.5 \mathrm{~mm}$ diameter PVC. The height of the rainfall simulator can be adjustable to maximum $200 \mathrm{~cm}$ height. The purpose of motor was to swing outlet valve so that the rain were equally distributed to all area of infiltration model because of bigger size of model. Power of motor was supplied by battery. A rainfall was applied about $70 \%$ from rainfall data record in field data. The applied rainfall was depending on experimental program and the remains $30 \%$ is assume to be surface runoff [5]. Table 2 shows the technical detail of rainfall simulator.

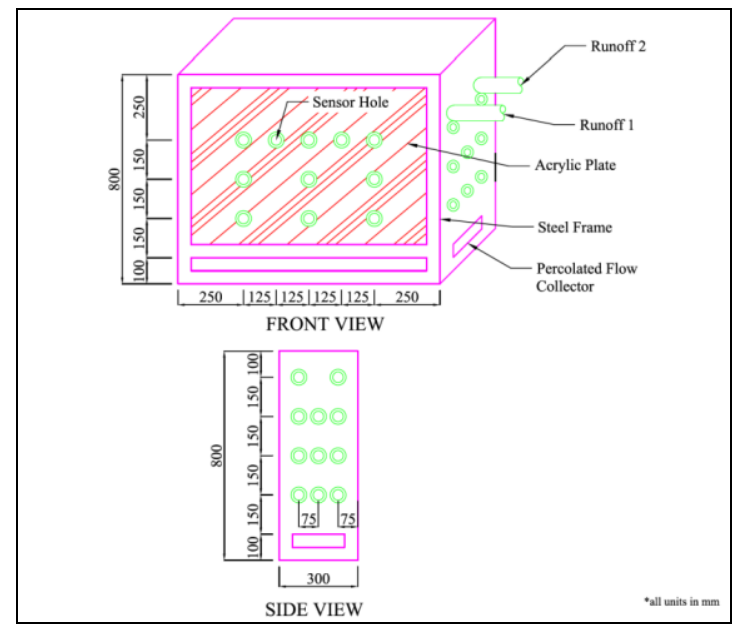

Fig. 4 - Schematic diagram for infiltration model box

Tensiometer and runoff collector were used as sensoring instrumentations. The tensiometers were connected to pressure transducer and from pressure transducer to data logger. The purpose of pressure transducer was to convert data from Ohm to $\mathrm{kPa}$. The datalogger used was the Campbell Scientific Data Logger, Model CR10x (Campbell Scientific Inc.). A program was written to set up communication and data collection between the data logger and instruments. The codes of the written program are presented in Appendix B. Data were recorded for every 1 minute. Fig. 5 shows the set up for infiltration test. The schematic diagram of the infiltration test setup is shown in Fig. 6.

Table 2 - Technical details of the rainfall simulator

\begin{tabular}{lc}
\hline Technical configuration & Parameter values \\
\hline Area & $1200 \mathrm{~mm} \times 1200 \mathrm{~mm}$ \\
Number of nozzles & $8 \mathrm{nos}$ \\
Space between nozzles & $150 \mathrm{~mm}$ \\
Height of fall & $1000 \mathrm{~mm}$ to $2000 \mathrm{~mm}$ \\
Water supply & Water level control \\
Rainfall intensity & $10^{-4} \mathrm{~m} / \mathrm{s}$ to $10^{-7} \mathrm{~m} / \mathrm{s}$ \\
\hline
\end{tabular}

An initial condition was creating for each type of soils in accordance to their actual field suction measurements during dry condition. The suggested initial suction approximated to the suction corresponding to residual water content [13]. All samples taken from site was air dried first. After the sample was dry, the sample was sieve according to size of Grade VI and Grade V properties. The preparation of sample was according to in-situ or bulk density of the soil. Next, the soil was mixed with water identical the residual water content for each soil. The residual water content for each soil was determined from soil water characteristic curve for each soil.

Lastly, process to fill up the soil in the model was done. The soil that already mixed with water was filled up in the model for every $100 \mathrm{~mm}$ height. The required mass of soil was computed based on that height. After that the sample was compact by using rubber tamping method. This process was continued until desired height achieved. Each layer of soil had $300 \mathrm{~mm}$ height; therefore the total height for the model is $600 \mathrm{~mm}$. After finished installed all the samples in the model, the tensiometer was installed at every design hole. The installation of tensiometer is shown in Fig. 7. The tensiometer was left for one day duration to stabilize the reading of tensiometer. The artificial of burrow holes was shown in Fig. 8. 


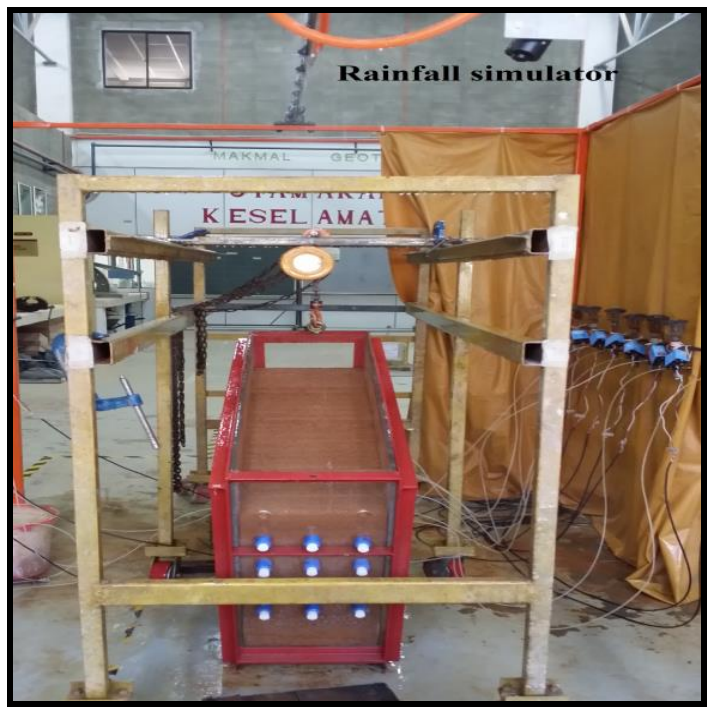

Fig. 5 - Set up for infiltration test

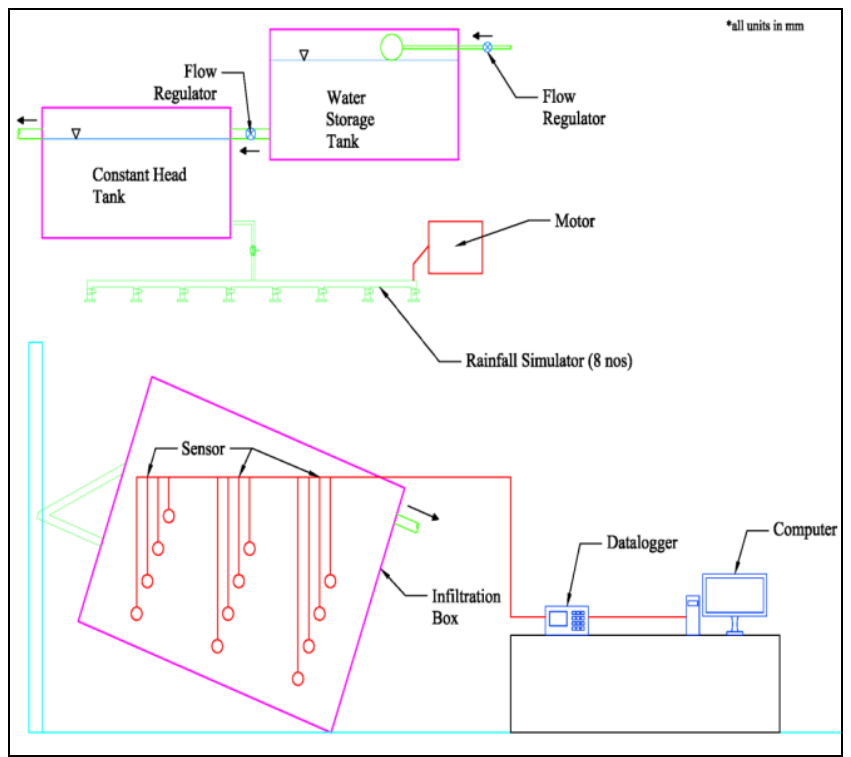

Fig. 6 - Schematic diagram of setup for infiltration test

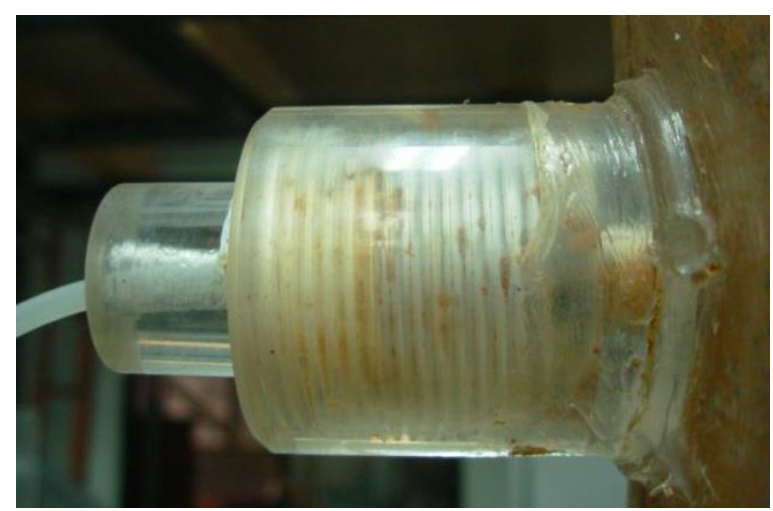

Fig. 7 - Installation of tensiometer 


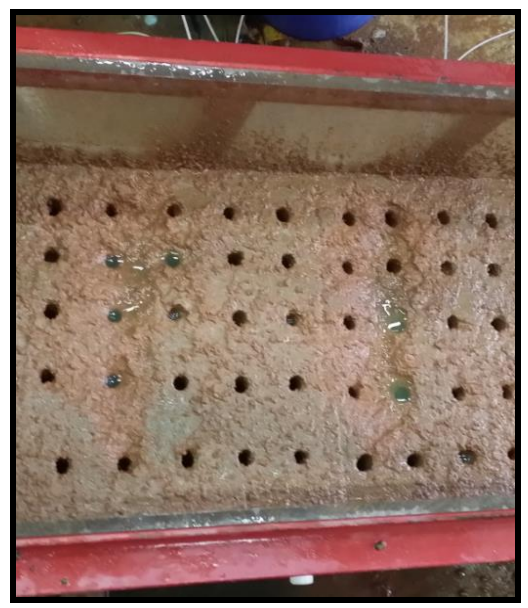

Fig. 8 - Artificial of burrow holes

Experimental programs were focused on performances of infiltration model of two-layer system consists of Grade VI (sandy silt) and Grade V (silty gravel). In Grade VI, the permeability of this layer varies from $5 \mathrm{x} 10^{-7} \mathrm{~m} / \mathrm{s}$ to $1.14 \mathrm{x}$ $10^{-4} \mathrm{~m} / \mathrm{s}$ which considers the existing of burrow hole in this soil layer. Table 3 tabulates the experimental program for this study.

Table 3 - Experimental programme for this study

\begin{tabular}{clcc}
\hline Exp. No & \multicolumn{1}{c}{ Soil Configuration } & $\begin{array}{c}\text { Rainfall } \\
\text { Intensity (m/s) }\end{array}$ & Duration \\
\hline A & Sandy silt (without burrow holes) underlain by silty gravel & $1.7196 \times 10^{-5}$ & 1 hour \\
B & Sandy silt (without burrow holes) underlain by silty gravel & $1.7694 \times 10^{-6}$ & 1 hours \\
C & Sandy silt (burrow holes A) underlain by silty gravel & $1.7196 \times 10^{-5}$ & 1 hour \\
D & Sandy silt (burrow holes A) underlain by silty gravel & $1.7694 \times 10^{-6}$ & 1 hours \\
E & Sandy silt (burrow holes B) underlain by silty & $1.7196 \times 10^{-5}$ & 1 hour \\
F & Sandy silt (burrow holes B) underlain by silty gravel & $1.7694 \times 10^{-6}$ & 1 hours \\
\hline
\end{tabular}

Table 4 - Permeability properties for each layer

\begin{tabular}{cc}
\hline \multicolumn{1}{c}{ Silty gravel } & $\begin{array}{c}\text { Saturated permeability, } \\
(\mathbf{m} / \mathbf{s})\end{array}$ \\
\hline Without burrow holes & $5.00 \times 10^{-7}$ \\
With burrow holes \\
$\begin{array}{c}\text { (A) } \\
\text { With burrow holes } \\
\text { (B) }\end{array}$ & $6.98 \times 10^{-4}$ \\
\hline
\end{tabular}

\section{Result and Discussion}

The first part in this section discusses the index properties of the residual soil and comparison with previous researcher. The second part discusses the result of infiltration test.

\subsection{Index Properties and Soil Classification}

The properties of Grade V and Grade VI soil of Balai Cerapan are shown in Table 5. These properties are in good agreement with those obtained by previous researchers [14-16]. 
Based from British Soil Classification System or BSCS, the classification of the soil was done for both soils. Grade VI was classified as sandy silt with high plasticity (MHS) and Grade V was classified as silty gravel of high plasticity (GMH).

\subsection{Modified Permeability Test}

The permeability of Grade VI with burrow holes was illustrated in Fig. 9. The graph shows that the burrow hole increased the coefficient of permeability, Ksat of Grade VI soil. Initially, without any burrow hole the coefficient of permeability was $5.0 \times 10^{-7} \mathrm{~m} / \mathrm{s}$. Introducing burrow hole in Grade VI layer with burrow hole area $3.53 \times 10^{-5} \mathrm{~m}^{2}$, the coefficient of permeability jumped to $2.47 \times 10^{-4} \mathrm{~m} / \mathrm{s}$. The coefficient of permeability, $\mathrm{K}_{\text {sat }}$ continue increased when increase the area of burrow holes. However, the coefficient of permeability, $\mathrm{K}_{\mathrm{sat}}$ almost achieved constant value as shown at last two points in the graph. This condition was discussed in literature, known as effect of radial distance of wetting front [17]. Radial distance of wetting front is effective area of burrow hole to infiltrate water. When the burrow hole is too close to each other, the infiltration rate decreased. The spacing of burrow hole is important to get maximum infiltration rate in the soil with burrow hole. It is can be concluded that for that particular area of permeability test, the maximum area of burrow area was achieved and by increase the area of burrow hole did not increase the coefficient of permeability, $\mathrm{K}_{\text {sat }}$.

Table 5 - Properties of Grade V and Grade VI residual soil

\begin{tabular}{lcc}
\hline Composition & Grade V & Grade VI \\
\hline Gravel (\%) & 48 & 0 \\
Sand (\%) & 15 & 33 \\
Silt (\%) & 20 & 34 \\
Clay (\%) & 17 & 33 \\
Liquid Limit (\%) & 53.2 & 59.3 \\
Plastic limit (\%) & 35.5 & 31.9 \\
Plasticity index & 17.7 & 27.4 \\
Moisture content $(\%)$ & 32 & 32 \\
Specific Gravity, $\mathrm{G}_{\mathrm{s}}$ & 2.63 & 2.65 \\
Bulk Density $\left(\mathrm{kg} / \mathrm{m}^{3}\right)$ & 1805 & 1415 \\
Dry Density $\left(\mathrm{kg} / \mathrm{m}^{3}\right)$ & 1366 & 1080 \\
$k_{\text {sat }}(\mathrm{m} / \mathrm{s})$ & $3.68 \times 10^{-6}$ & $5.0 \times 10^{-7}$ \\
\hline
\end{tabular}

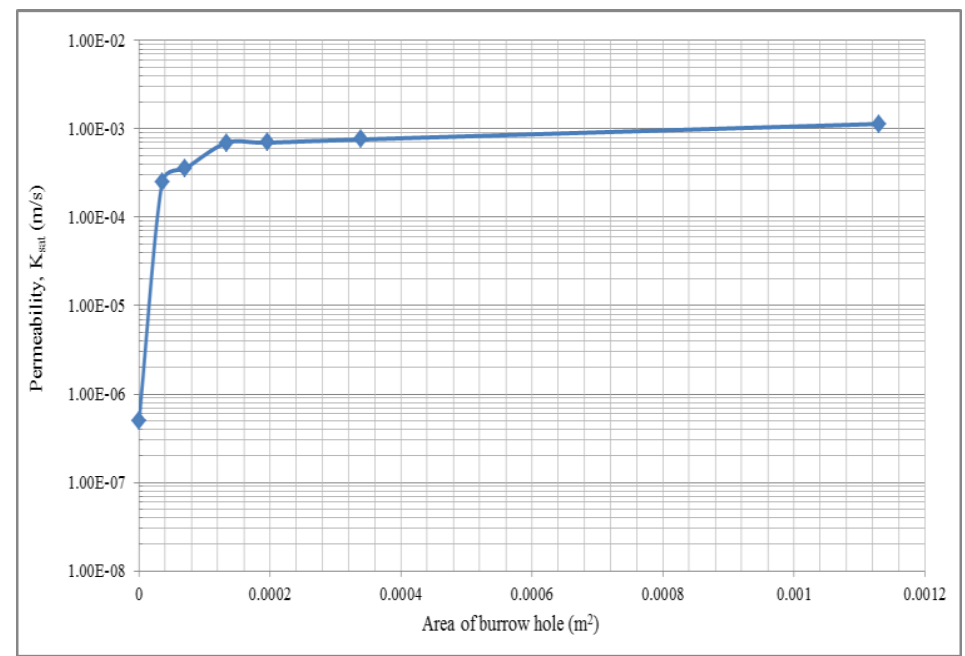

Fig. 9 - Coefficient of saturated permeability of Grade VI with existing of burrow hole 
Finally, the result concluded that the burrow hole influences the coefficient of permeability of soil. Increasing number of burrow hole is also increasing the coefficient of permeability of soil. For that reason, for the purposes infiltration test with existing burrow hole, two area of burrow hole were selected; the maximum value $1.14 \mathrm{x} 10^{-3} \mathrm{~m} / \mathrm{s}$ and average value at the middle of graph $6.98 \times 10^{-4} \mathrm{~m} / \mathrm{s}$. Table 6 tabulated saturated permeability for sandy silt with existing of burrow hole.

Table 6 - Saturated permeability for Grade VI with existing burrow hole

\begin{tabular}{cc}
\hline Area of burrow holes $\left(\mathbf{m}^{2}\right)$ & Saturated permeability, $\mathbf{K}_{\text {sat }}(\mathbf{m} / \mathbf{s})$ \\
\hline 0 & $5.00 \times 10^{-7}$ \\
$3.53 \times 10^{-5}$ & $2.47 \times 10^{-4}$ \\
$7.07 \times 10^{-5}$ & $3.56 \times 10^{-4}$ \\
$1.34 \times 10^{-4}$ & $6.98 \times 10^{-4}$ \\
$1.96 \times 10^{-4}$ & $7.00 \times 10^{-4}$ \\
$3.39 \times 10^{-4}$ & $7.60 \times 10^{-4}$ \\
$1.13 \times 10^{-3}$ & $1.14 \times 10^{-3}$ \\
\hline
\end{tabular}

\subsection{Infiltration test}

Fig. 9 shows suction distribution for residual soil slope without burrow holes. The result shows that very minor change in suction distribution for upper layer (from $22.55 \mathrm{kPa}$ to $22.25 \mathrm{kPa}$ ) and no changes in interfaces and bottom layer.

Meanwhile Fig. 10 illustrates suction distribution for residual soil slope with burrow holes with coefficient of permeability of $6.98 \times 10^{-4} \mathrm{~m} / \mathrm{s}$. The result indicates that no changes in suction until 40 minutes time rainfall. In 40 minute, time and 50 minute time, the suction start to decrease at upper layer and interfaces but still remain unchanged at bottom layer. At the end of testing or 60-minute time testing, matrix suction at bottom layer declined from $27.87 \mathrm{kPa}$ to $24.16 \mathrm{kPa}$.

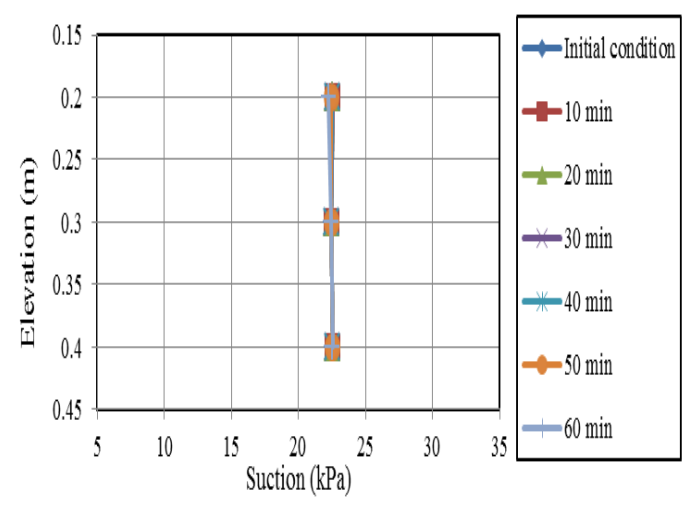

Fig. 10 - Suction distribution for residual soil without burrow holes

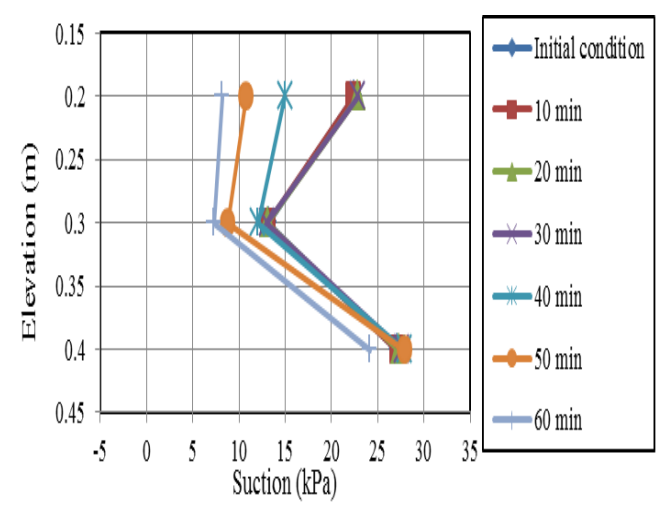

Fig. 11 - Suction distribution for residual soil with burrow holes $6.98 \times 10^{-4} \mathrm{~m} / \mathrm{s}$

Suction distribution for residual soil slope with burrow holes with coefficient of permeability of $1.14 \times 10^{-3}$ was shown in Fig. 11. In 10 minute time, there was changed of suction at upper layer from $23.57 \mathrm{kPa}$ to $22.55 \mathrm{kPa}$. For 
interface and bottom layer, matrix suction increase from 12.97 to 13.07 at interface and $24.69 \mathrm{kPa}$ to $25.38 \mathrm{kPa}$ for bottom layer. However, after 20 minute time, suction distribution for all layers was parallel, that explain water was fully infiltrate to all layers.

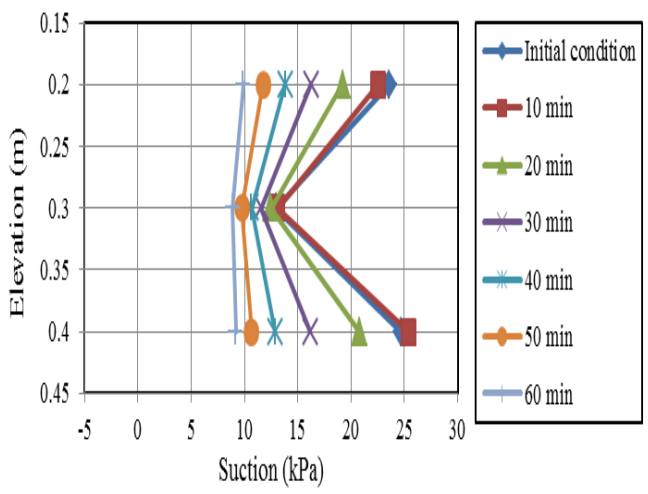

Fig. 12 - Suction distribution for residual soil with burrow holes $1.14 \times 10^{-3} \mathrm{~m} / \mathrm{s}$

According to [18] when ration rainfall intensity and permeability of soil, $q / \mathrm{k}_{\text {sat }}$ is greater than 1 the run off will occur due to excess water for soil to absorb. On the other hand, when the ratio of $\mathrm{q} / \mathrm{k}_{\mathrm{sat}}$ is less than 1 , all rainfall will infiltrate into soil layer. Table 6 tabulated the $\mathrm{q} / \mathrm{k}_{\text {sat }}$ ratio for all rainfall pattern and soil layer. The result on rainfall pattern 1 and rainfall pattern 2 with Grade VI without burrow hole shows the ratio greater than 1 . Meanwhile for all others have the value less than 1 , range from 0.025 to 0.0016 . Therefore, this ratio explained why the change matrix suction more pronounced for suction distribution in Grade VI layer with burrow holes, either $6.98 \times 10^{-4} \mathrm{~m} / \mathrm{s}$ or $1.14 \mathrm{x}$ $10^{-3} \mathrm{~m} / \mathrm{s}$

Table 7: Ratio of $q /$ Ksat for all type of rainfall and soil layer Grade VI

\begin{tabular}{|c|c|c|}
\hline Permeability of Grade VI & $\begin{array}{l}\text { Rainfall intensity } 1 \\
1.72 \times 10^{-5} \mathrm{~m} / \mathrm{s}\end{array}$ & $\begin{array}{l}\text { Rainfall intensity } 2 \\
1.77 \times 10^{-6} \mathrm{~m} / \mathrm{s}\end{array}$ \\
\hline $\begin{array}{l}\text { Residual soil without burrow holes } \\
\qquad\left(5.0 \times 10^{-7} \mathrm{~m} / \mathrm{s}\right)\end{array}$ & Experimental A1 with ratio 34.4 & Experimental A2 with ratio 3.54 \\
\hline $\begin{array}{l}\text { Residual soil with burrow holes } \\
\qquad\left(6.98 \times 10^{-4} \mathrm{~m} / \mathrm{s}\right)\end{array}$ & Experimental B 1 with ratio 0.025 & Experimental B2 with ratio 0.0025 \\
\hline $\begin{array}{l}\text { Residual soil with burrow holes } \\
\qquad\left(1.14 \times 10^{-3} \mathrm{~m} / \mathrm{s}\right)\end{array}$ & Experimental $\mathrm{C} 1$ with ratio 0.015 & Experimental $\mathrm{C} 2$ with ratio 0.0016 \\
\hline
\end{tabular}

For ratio more than 1 , in this case ratios of 3.54 and 34.4 , minor changes of matric suctions were recorded from initial condition to 1 hour time. The matric suction changes from $22.55 \mathrm{kPa}$ at initial to $22.25 \mathrm{kPa}$ after 1 hour for ratio of 34.4 and matric suction changes from $23.61 \mathrm{kPa}$ at initial to $22.85 \mathrm{kPa}$ at the end of testing for ratio of 3.54 . These results explained that only a little rainfall infiltrate into the soil layer and the rest of rainfall becomes the runoff water, therefore the changes of matric suction are not dominant.

For ratio less than 1, can be discuss into 2 conditions; firstly for ratio 0.025 and 0.015 (two orders of magnitude) and secondly for ratio 0.0025 and 0.0015 (three order of magnitude). The result for two orders of magnitude illustrates that the matric suction jumps at 40 minutes time from $22.85 \mathrm{kPa}$ to $14.98 \mathrm{kPa}$ (for 0.0025 ratios) and from $22.43 \mathrm{kPa}$ to $17.52 \mathrm{kPa}$ (for ratio 0.015 ) and both continue decrease to $8.17 \mathrm{kPa}$ at the end of testing. The situations explained that the rainfall accumulated at top part of soil before percolated into the soil. This is may be the reason why the matric suction suddenly drops at 40 minutes time.

Meanwhile, for three orders of magnitude, the result shows the matric suction started to decrease as early as 10 minutes time. Both conditions continue decline until end of testing and stop at $9.86 \mathrm{kPa}$. In this phenomenon, the rainfall starts to infiltrate into the soil as the testing started. The change of matric suction for different ratio is shown in Fig. 9. 


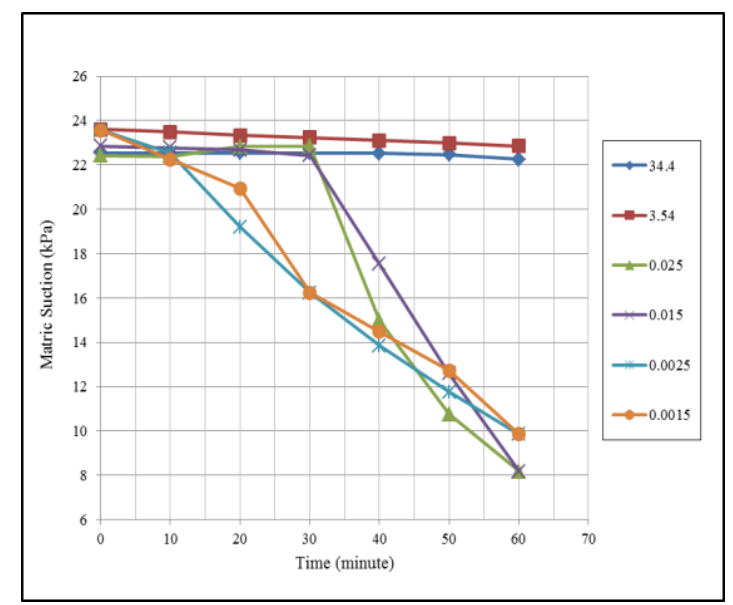

Fig. 13 - Suction distribution in residual soil slope for different ratio

The result explained that with existing burrow holes in Grade VI soil layer and reverse condition of capillary barrier effect can cause more infiltrating water into soil layer. At the end of testing period, the soil was carefully excavated to investigate the water flow in the soil as shown in Fig. 13. The visual observation shows that the water filled up the holes. The existing of burrow holes as a drainage in the residual soil slope therefore the infiltrating water can easily infiltrate into deeper layer.

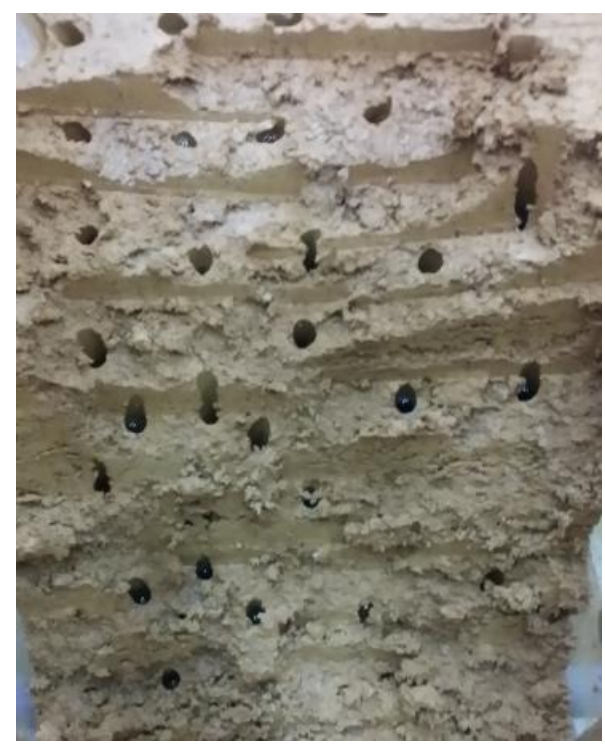

Fig. 14 - Infiltrating water hold in the burrow hole

\subsection{Conclusion}

As conclusion, the existing of burrow holes in Grade VI or sandy silt greatly influences the suction distribution in the soil profile. The existing of burrow holes changes the permeability of original soil which will cause major change in matrix suction. The flow mechanism of soil profile without burrow holes because of capillary effect. The mechanism of capillary barrier will be developed at the interface, where the upper layer has lower permeability than bottom layer. Meanwhile the flow mechanism for soil profile with burrow holes at Grade VI shows that the infiltrating water can easily penetrate into bottom layer.

\section{References}

[1] W. Chao, L. Min, H. Cai, H. Jie, F. C. Dai, and M. Long, (2013). Combined roles of saturated permeability and rainfall characteristics on surficial failure of homogeneous soil slope, vol. 153, pp. 105-113.

[2] F. Bastardie, Y. Capowiez, J. R. De Dreuzy, and D. Cluzeau, (2003). X-ray tomographic and hydraulic characterization of burrowing by three earthworm species in repacked soil cores, Appl. Soil Ecol., vol. 24, no. 
1, pp. 3-16.

[3] S. R. J. Keith, (1992). The relation of earthworms to soil hydrailic properties, Soil Biol. Biochem., vol. 24, no. 12, pp. 1539-1543.

[4] S. S. Agus, E.-C. Leong, and H. Rahardjo, (2005). Estimating permeability functions of Singapore residual soils," Eng. Geol., vol. 78, no. 1-2, pp. 119-133.

[5] H. Rahardjo, A. Satyanaga, E.-C. Leong, Y. S. Ng, and H. T. C. Pang, (2012). Variability of residual soil properties," Eng. Geol., vol. 141-142, pp. 124-140.

[6] H. Rahardjo, A. Satyanaga, and E.-C. Leong, (2013). Effects of flux boundary conditions on pore-water pressure distribution in slope," Eng. Geol., vol. 165, pp. 133-142.

[7] H. Rahardjo, E. Leong, and R. Rezaur, (2008). Effect of antecedent rainfall on pore-water pressure distribution characteristics in residual soil slopes under tropical rainfall, Hydrol. Process., vol. 523, no. October 2007, pp. $506-523$.

[8] T. Zhan and C. Ng, (2004). Analytical analysis of rainfall infiltration mechanism in unsaturated soils, Int. J. Geomech., no. December, pp. 273-284.

[9] N. Gofar, M. Lee, and A. Kassim, (2012). Effect of surface boundary condition on rainfall infiltration, J. Teknol., vol. 44, pp. 63-70.

[10] B. B. K. Huat, F. H. J. Ali, and T. H. Low, (2006). Water infiltration characteristics of unsaturated soil slope and its effect on suction and stability, Geotech. Geol. Eng., vol. 24, no. 5, pp. 1293-1306.

[11] A. Ibrahim, M. Mukhlisin, and O. Jaafar, (2013). Numerical assessment of rainfall infiltration into soil column for the unsaturated layered residual forest soil, J. Teknol. Sciences Eng., vol. 65, no. 2, pp. 121-127.

[12] A. Kassim, N. Gofar, L. M. Lee, and H. Rahardjo, (2012). Modeling of suction distributions in an unsaturated heterogeneous residual soil slope, Eng. Geol., vol. 131-132, pp. 70-82.

[13] N. Gofar and L. M. Lee, (2008). Response of suction distribution to rainfall infiltration in soil slope selection of study areas, electron. J. Geotech. Eng.

[14] S. Maail, B. Huat, and S. Jamaludin, (2004). Index, engineering properties and classification of tropical residual soils., Trop. residual soils, no. Blight 1997, pp. 37-55.

[15] H. Rahardjo, V. A. Santoso, E. C. Leong, Y. S. Ng, and C. J. Hua, (2012). Performance of an Instrumented Slope Covered by a Capillary Barrier System, J. Geotech. Geoenvironmental Eng., vol. 138, no. 4, pp. 481490.

[16] Z. Rahman and U. Hamzah, (2010). Influence of oil contamination on geotechnical properties of basaltic residual soil, Am. J. Appl. Sci., vol. 7, no. 7, pp. 954-961.

[17] M. Weiler, (2005). An infiltration model based on flow variability in macropores: development, sensitivity analysis and applications, J. Hydrol., vol. 310, no. 1-4, pp. 294-315.

[18] N. Gofar and L. Min Lee, (2008). Extreme rainfall characteristics for surface slope stability in the Malaysian Peninsular, Georisk Assess. Manag. Risk Eng. Syst. Geohazards, vol. 2, no. 2, pp. 65-78. 